Reseñas

\title{
Statistics as a discipline: A brief look to the past, the present and the future
}

La estadística como una disciplina: una breve mirada al pasado, al presente y al futuro

A Estatística como disciplina: um breve olhar sobre o passado, o presente e o futuro

Mario Miguel Ojeda Ramírez Universidad Veracruzana, Facultad de Estadística e Informática, México mojeda@uv.mx https://orcid.org/0000-0001-6161-3968

Roberto Behar Gutiérrez

Universidad del Valle, Facultad de Ingeniería, México roberto.behar@correounivalle.edu.co https://orcid.org/0000-0001-6472-038X

Pere Grima Cintas

Universidad Politécnica de Cataluña, Departamento de Estadística e Investigación Operativa, España

pere.grima@upc.edu http://orcid.org/0000-0003-1470-1230 


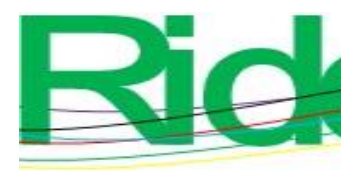

Revista Iberoamericana para la
Investigación y el Desarrollo Educativo

ISSN $2007-7467$

\section{Abstract}

Statistics have become especially important in the information and knowledge age. Professionals and scientists, and also citizens, recognize that it helps in the collection, organization and analysis of data, and that its principles support the interpretation and communication of the results obtained. It is accepted that it is a methodology to obtain knowledge, and likewise a technology, that supports diagnoses, interventions and decision-making in contexts of uncertainty. This essay presents a broad and fair conceptualization of this discipline. It also makes a characterization of its mission and briefly reviews its history, trends and current status. At the end, a brief vision of the prospects for the future is presented.

Keywords: Statistical methodology, History of statistics, Teaching statistics, Information and knowledge society, Applied statistics

\section{Resumen}

La estadística ha adquirido especial importancia en la era de la información y el conocimiento. Los profesionales y científicos, y también los ciudadanos, reconocen que ayuda a la recopilación, organización y análisis de datos, y que sus principios apoyan la interpretación y comunicación de los resultados obtenidos. Se acepta que es una metodología para obtener conocimiento, y así mismo una tecnología, que respalda diagnósticos, intervenciones y la toma de decisiones en contextos de incertidumbre. Este ensayo presenta una conceptualización amplia y justa de esta disciplina. También hace una caracterización de su misión y revisa brevemente su historia, tendencias y estado actual. Al final se presenta una breve visión de las perspectivas para el futuro.

Palabras clave: Metodología estadística, Historia de la estadística, Enseñanza de la estadística, Sociedad de la información y el conocimiento, Estadística aplicada. 


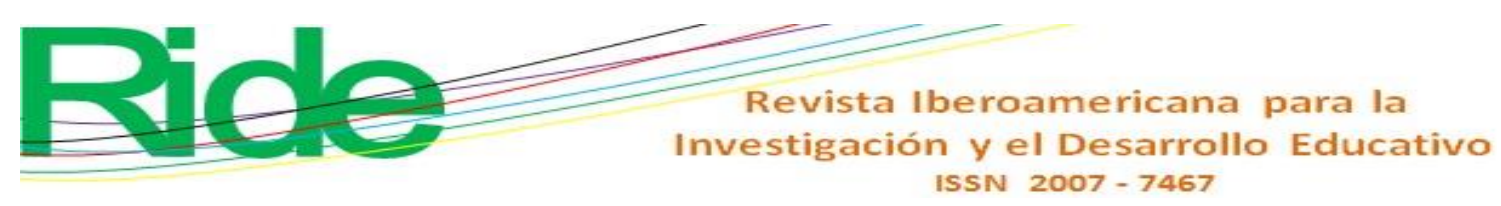

\section{A historical sketch}

Statistics has been practiced since the dawn of civilization. The Babylonians, Egyptians, Chinese, Mayans and Incas and all later cultures used to compile and analyze data in the form of counts and quantities, which we now call statistics.

The first formal census was conducted in England in 1066, commissioned by king William I. The emergence of statistics as a scientific discipline set on a systematic foundation is associated with Graunt (1620-1674) who studied mortality in London, and the astronomer Halley (1656-1742), who also contributed to vital statistics. Fienberg (1992), in a famous historical review essay, established the period of the development of probability and the exposition of no probabilistic methods of data analysis as pre-history, and pointed out that the statistical discipline history proper begins around 1750. From this period on development continues in two streams: the socio-demographic and mathematical-encyclopedic. The former culminates in the founding of demography as a discipline, and the latter leads to Statistics in their current form. An important reference about the History of Statistics is Fienberg (1992), who called the period 1750-1820 as The introduction of inference and the beginning of mathematical statistics; he reviewed the significant contributions made by Bernoulli (1700-1782), Bayes (1702-1761), Laplace (17491827) and Gauss (1777-1855), mainly; continuing the Fienberg's historical review, the period from 1820 to 1900, which was labeled as The socialization of statistics and the development of correlation and statistical models and was characterized by the contributions of Quetelet (17961874), Galton (1822-1911) and Karl Pearson (1857-1936), between others; they where laid foundations of a theory that supports modern statistics as a scientific discipline and a profession. 


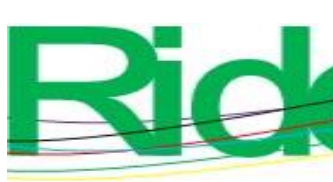

Revista Iberoamericana para la Investigación y el Desarrollo Educativo ISSN $2007-7467$

Figure 1. Timeline of the development of Statistics as a discipline (adapted from Fienberg, 1992).

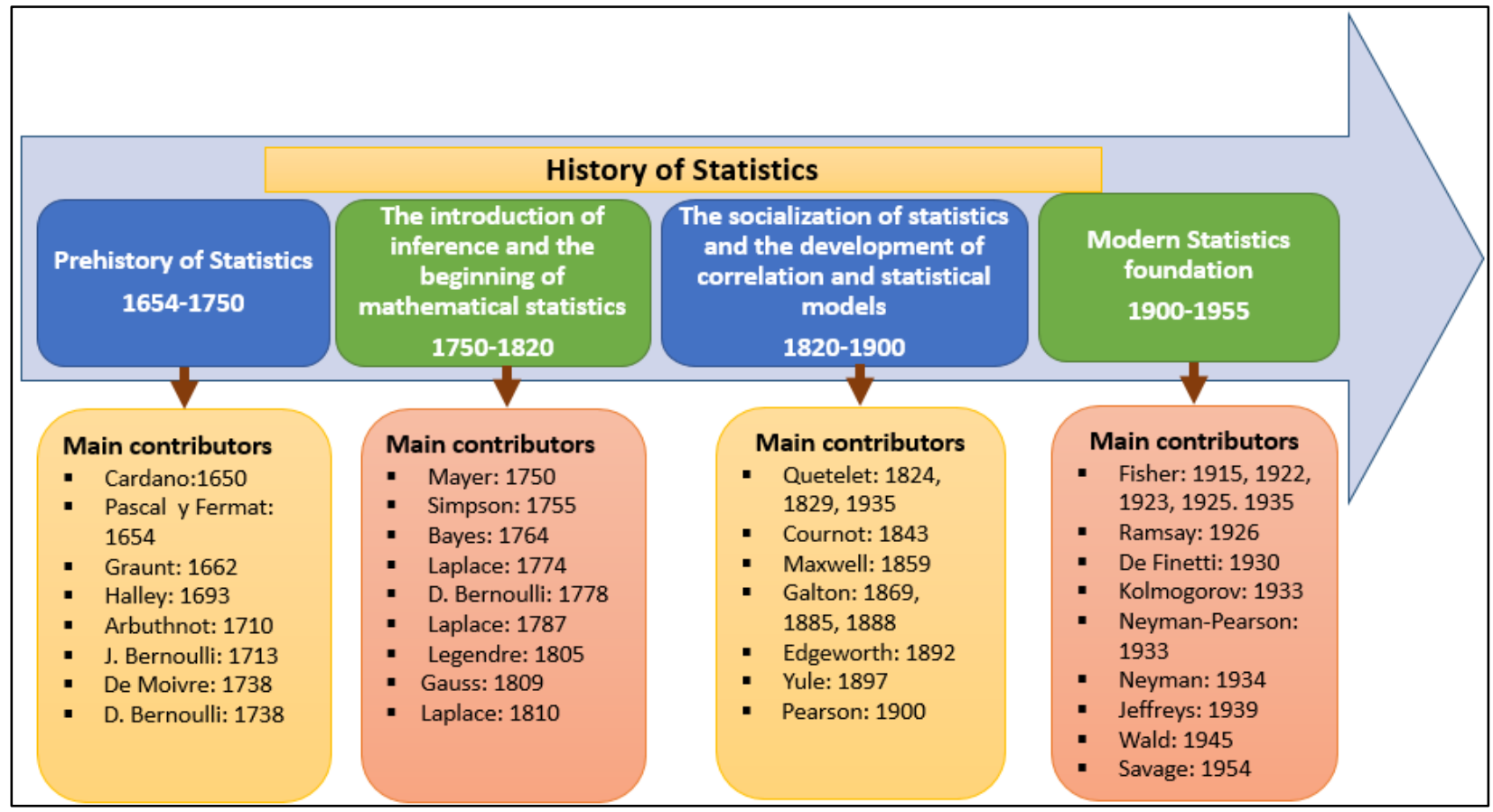

Source: Own elaboration using the periods proposed by Fienberg (1992).

These foundations were further developed and set on a firm basis in the 20th century by Fisher (1892-1962), Egon Pearson (1895-1980) Neyman (1894-1981) and Lehmann (1917-2009), between others (see Figure 1). Cox (2016) presents a series of personal reflexions about the work of nine major figures working mostly in the earlier two-thirds of the 20th century, which includes R. A. Fisher, E. S. Pearson, Neyman and: H. Jeffreys (1891-1989), M. S. Bartlett (1901-2001), F. Yates (1902-1984), L. J. Savage (1917-1971), H. E. Daniels (1912-2000) and J. W. Tukey (1915-2000).

R. A. Fisher is considered as the father of modern Statistics. He made important contributions to statistical methodology, motivated by problems in Genetics, Biology and Agriculture. These methods were soon found to be applicable more generally, in industry and social sciences, wherever experimentation and controlled scientific observation is planned. Fisher's reference to statistical method as a 'scientific method' confirms that statistics is a science on par with all others.

The period from 1930s to 1960s saw a rapid expansion of research and application of statistical methodology. Statistics was introduced in research centers concerned with industrial and agricultural production. 
A community of professionals in statistics was formed. The subject was introduced in universities, was added to curricula of courses in Agronomy, Biology, Psychology, Economics, Medicine and Engineering. Statistics departments and consulting laboratories were founded.

In the 1950s and 1960s, Statistics became widely recognized, although its application and related research is hampered by the tedious tasks of calculation using primitive equipment. With the advent and proliferation of computers, the techniques of data management and analysis have become an essential part of the social and economic life in the developed countries. From the 1970s on, computers and software implemented on them begin the process of simplifying the application of statistical techniques, moving information from paper-based records to electronic files, making their interrogation fast and flexible and raising the potential of statistical analysis is general.

With this proliferation come a variety of ills, such as disregard for the various assumptions and other misuse of statistical methods. Computer processing time is becoming less and less a concern even for the most extensive operations in data management and iterative inferential algorithms. User-friendly and interactive software with extensive help facilities cuts down the effort needed to master it and promotes their widespread use. The facility with which information is spread in the society and how communication technologies become ubiquitous are changing the paradigm of society of knowledge. These advances in computational capacities have allowed to tackle complex problems, difficult to model with the theory, using a powerful tool that nowadays, it is of extended use: the Monte Carlo simulation. On the other hand, the problem of the restrictions imposed by the assumptions of the statistical methods, have been able to be tackled with nonparametric strategies of intensive computation, like the Bootstrap, of wide acceptance in topicality by the academic community (Efron, 1979).

This brief historical sketch indicates that statistics has developed at a rapid pace throughout the 20th century. The following stepping-stones can be identified in this development:

1. A solid mathematical theory, in particular the axiomatic definition of probability by Kolmogorov (1903-1987), which is the basis of all statistical methodology concerned with management of uncertainty.

2. Personal computers with abundant storage capacity and fast processors and software implemented on them. Dissemination of statistical methods to all areas where information is collected and analyzed. Promotion of methods from the academic and research environment to 


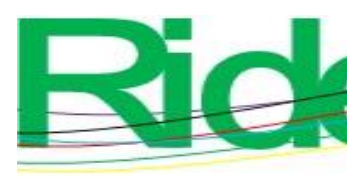

Revista Iberoamericana para la Investigación y el Desarrollo Educativo ISSN 2007-7467

In general, as regards the statistical training of non-statistical professionals, the trend is to remove the calculations, as the center of the teaching and strengthening statistical thinking. On the other hand, to change the approach of teaching tools to answer research questions, considering the whole process, since the approach of the problem and the generation of the data; against the tendency to consider statistics only like data analysis. These changes strengthen the phase of the transit of the real world to the symbolic world as well as in the opposite direction (Batanero, 2019).

\section{Conclusions}

Under the actual conception, we expect a growth in the demand of data scientists in the workspaces in new niches, considering the dynamics of development that we have presented. Data scientists work in gathering data, in processing for obtaining useful information, and presenting that information to decision making. Data scientists do not focus on a single source but look at data from multiple sources to enable them to predict trends and forecast and interpret results from the collected data. Several studies indicated that data scientists are experienced professionals with possessing skills on data processing or data visualization, programming language, statistical packages, office applications and databases (Anderson-Cook et al., 2019). Data scientists appear to be closely related to statisticians but also to big data. In the case of developing societies in the immediate future the labor market for professionals in Statistics is much more flattering, as there is a large deficit of these professionals; of course they should be prepared to adapt to the rapid changes that discipline suffer. H. G. Wells did say, "Statistical thinking will on day be as necessary a qualification for efficient citizenship as the ability to read and write". The statistic is just now part of a new culture that emerges: the called information and knowledge society, and in this sense, statistics should expand all the influences. The future is here.

\section{Future lines of research}

The history of statistics has run its course; however, after the essay by Fienberg (1992), few are the integrative and synthesizing works that have been published. This essay is located along this line, from which several challenges arise. The first is to make a detailed analysis of the main events after the 1950s. Here, without a doubt, the role that the computer and statistical packages have played is decisive. This will lead to the identification of aspects such as business 


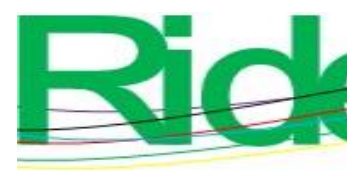

Revista Iberoamericana para la Investigación y el Desarrollo Educativo ISSN $2007-7467$

intelligence and data mining, leading to "data science"; It is also important to locate the role of the Quality Revolution and the development of industrial and business statistics. Rao \& Székely (2000) and Tanner \& Wells (2000), among others, present reviews, from different areas of the discipline, of the perspectives of statistics for the 21 st century, which is a basis for undertaking a synthesis work. Many journals include works on the history of statistics, some even at the section level, such as The American Statistician, which indicates the relevance of this topic.

\section{Acknowlegdes}

This work was carried out while the authors meetuped in Veracruzana University, in several conferences during six years ago. We acknowledge the support from Nick Longford for his careful reading of several previous versions, and his comments and useful suggestions that have improved the quality and the readability of the paper. We also thank the anonymous reviewers for their comments and suggestions for improving our review and the expository strategy.

\section{References}

Anderson-Cook, C. M., Lu, L., \& Parker, P. A. (2019). Effective interdisciplinary collaboration between statisticians and other subject matter experts. Quality Engineering, 31(1), 164176.

Batanero, C. (2019). Thirty years of research in stochastic education: Reflections and challenges. [Treinta años de investigación en educación estocástica: Reflexiones y desafíos.] In J. M. Contreras, M. M. Gea, M. M. López-Martín \& E. Molina-Portillo (eds.). Actas del Tercer Congreso Internacional Virtual de Educación Estadística. www.ugr.es/local/fqm126/civeest.html

Berger, J. O. (2002). Bayesian analysis: a look at today and thoughts of tomorrow. In A. E. Raftery, M. A. Tanner \& M. T. Wells (eds.). Statistics in the $21^{\text {st }}$ Century. $\quad$ (pp. 275-290). Chapman and Hall.

Cox, D. R. (2016). Some pioneers of modern statistical theory: a personal reflection. Biometrika, 103(4), 747-759.

Efron B. (1979). Bootstrap methods: Another look at the Jackknife. The Annals of Statistics, 7, 15-30.

Fienberg, S. E. (1992). A brief history of statistics in three and one-half chapters: A review essay. Statistical Science, 12(2), 208-225. 


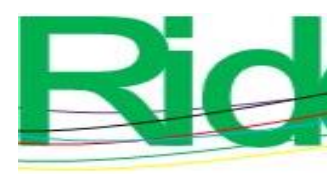

Revista Iberoamericana para la Investigación y el Desarrollo Educativo ISSN 2007 - 7467

Fienberg, S. E. (2014). What is statistics? Annual Review of Statistics and its Applications, 1, 1-9. Longford, N. (2013). Statistical decision theory. Springer Verlag.

Rao, C. R. \& Székely, G. J. (eds.) (2000). Statistics for the $21^{\text {st }}$ century. Marcel Dekker.

Tanner, M. A., \& Wells M. T. (eds.). (2002). Statistics in the $21^{\text {st }}$ Century. (pp. 275-290). Chapman and Hall.

Van Dyk D. A. (2014). The role of statistics in the discovery of a Higgs Boson. Annual Review of Statistics and its Application, 1, 41-59.

Wild, C. J. \& Pfannkuch, M. (1999). Statistical thinking in empirical enquiry. International Statistical Review, 67(3), 223-265.

\begin{tabular}{|l|l|}
\hline Rol de Contribución & Autores \\
\hline Conceptualización & $\begin{array}{l}\text { Mario Miguel Ojeda Ramírez (Principal), Roberto } \\
\text { Behar Gutiérrez (Igual) y Pere Grima Cintas (Igual) }\end{array}$ \\
\hline $\begin{array}{l}\text { Escritura - Preparación del } \\
\text { borrador original }\end{array}$ & $\begin{array}{l}\text { Mario Miguel Ojeda Ramírez (Principal), Roberto } \\
\text { Behar Gutiérrez (Apoya) y Pere Grima Cintas } \\
\text { (Apoya) }\end{array}$ \\
\hline $\begin{array}{l}\text { Escritura - Revisión y } \\
\text { edición }\end{array}$ & $\begin{array}{l}\text { Mario Miguel Ojeda Ramírez (Principal), Roberto } \\
\text { Behar Gutiérrez (Apoya) y Pere Grima Cintas } \\
\text { (Apoya) }\end{array}$ \\
\hline Adquisición de fondos & Mario Miguel Ojeda Ramírez \\
\hline
\end{tabular}

